\title{
Occurrence of the genus Pseudoboletia (Echinoidea: Toxopneustidae) in the South-Western Atlantic: morphological and molecular approaches
}

\author{
Elinia M. Lopes ${ }^{1}$, Carlos Eduardo L. Ferreira ${ }^{2} \&$ Carlos Renato R. Ventura ${ }^{1}$ \\ 1. Departamento de Invertebrados, Laboratório de Echinodermata, Museu Nacional/Universidade Federal do Rio de \\ Janeiro, Quinta da Boa Vista s/no, Rio de Janeiro, Brazil; elinialopes@gmail.com/ventura@acd.ufrj.br \\ 2. Departamento de Biologia Marinha, Universidade Federal Fluminense, Outeiro São João Batista s/no ${ }^{\circ}$, Niterói, Brazil; \\ carlosferreira@id.uff.br
}

Received 21-V-2017. Corrected 22-VI-2017. Accepted 10-VIII-2017.

\begin{abstract}
The genus Pseudoboletia was recently reported off coast of Brazil (Trindade-Martin Vaz insular complex). This study reports the first record of this genus to southern of Brazil in Rio de Janeiro and Santa Catarina coasts. Morphological and molecular data showed that sea urchins from Brazil and São Tomé are the same species, genetically distinct of individuals from Indo-Pacific. However, taxonomic identity of Brazilian species remains as a challenge. Two hypotheses to explain the recent records of this species on Brazilian coast are discussed: a recent natural invasion by long-distance dispersal and a recent population expansion in the Brazilian coast after absence or low density period. Rev. Biol. Trop. 65(Suppl. 1): S299-S308. Epub 2017 November 01.
\end{abstract}

Key words: sea urchin; Brazilian coast; new record; population expansion; long distance dispersal.

The sea urchin genus Pseudoboletia Troschel, 1869 is distributed from shallow-water zones to 100 meters depth through tropical and subtropical regions of the Atlantic and IndoPacific oceans (Mortensen, 1943; Pawson, 1978; Turner \& Graham, 2003). The species occur over sand or rock bottom and normally cover the test with algal and shells. Pseudoboletia belongs to the family Toxopneustidae Troschel, 1872, which includes eight living genera. In the Brazilian coast, two toxopneustid species are commonly found: Lytechinus variegatus (Lamarck, 1816) and Tripneustes ventricosus (Lamarck, 1816). Recently, the genus Pseudoboletia has been reported to shallow-water of Trindade Archipelago (1200 $\mathrm{km}$ east of the coast, the most eastward point of Brazilian territory $20^{\circ} 31^{\prime} 29^{\prime \prime} \mathrm{S}-2^{\circ} 19^{\prime} 29^{\prime \prime}$ W) (Martins, Souto, Braga, \& Tavares, 2016). The present study indicates two new records for Pseudoboletia (Rio de Janeiro and Santa
Catarina) extending its range in to subtropical waters from southeastern to southern coast.

The taxonomic status and phylogenetic affinities among Pseudoboletia species still have many gaps and uncertainties. Mortensen (1943) highlights the difficulty in sharply delimiting these species, mainly because few and poorly preserved individuals were used in the original description. The morphological differences among species pointed out by Mortensen (1943) were basically: (1) the number of the pore-pairs in pore-arcs and (2) the presence of dark spots (macula) on the test and spines. Four species of the genus are recognized by Mortensen (1943) and are currently considered valid in Word Register of Marine Species database (WoRMS): Pseudoboletia maculata Troschel, 1869 from Indo-Pacific and North-Western Atlantic, Pseudoboletia indiana (Michelin, 1862) from Indo-Pacific, Pseudoboletia atlantica Clark, 1912 from South Atlantic 
Ocean (Ascension and St. Helena Islands) and Pseudoboletia occidentalis Clark, 1921 from North Atlantic (Barbados and Antigua Island). Despite that, synonyms and subspecies were described posteriorly. Pawson (1978) synonymized $P$. occidentalis and $P$. maculata considering morphological characters. Additionally, Pawson (1978) described two subspecies of $P$. maculata differentiated by the number of porepair of podia: P. maculata maculata Troschel, 1869 from Indo-Pacific oceans and NorthWestern Atlantic (with four pore-pair of podia) and Pseudoboletia maculata atlantica Clark, 1912 from St. Helena and Ascension Islands (with predominantly five pore-pair of podia). The species $P$. indiana and $P$. maculata were designated as synonyms by Liao and Clark (1995), making Pseudoboletia a monotypic genus. According to Liao and Clark (1995) the test morphology of the $P$. indiana and $P$. maculata are identical except for differences in the color pattern (absence of dark spots in $P$. indiana). However, this classification was not followed by subsequent studies. Moreover, the species status of the $P$. indiana was confirmed by molecular analysis (Zigler, Byrne, M., Raff, Lessios, \& Raff, 2012). P. indiana and $P$. maculata maculata from Indo-Pacific are distinct species with $7.3 \%$ of the genetic divergence (Cytochrome oxidase I sequences) (Zigler et al., 2012). According to Zigler et al. (2012), hybridization between them can occur in sympatric populations at Sydney coast (Southeastern Australia), where individuals with intermediate coloration are reported. The authors also included in the analyses Pseudoboletia samples from São Tomé Island (SouthEastern Atlantic Ocean). Individuals from São Tomé were distinct species, different from $P$. indiana and P. maculata of Indo-Pacific region. Therefore, Zigler et al. (2012) referred the individuals from São Tomé Island as Pseudoboletia sp. As a genus occurring globally, from tropical to temperate provinces, the biogeographic scenario involved suggests an interesting case for evolutionary and phylogeographic studies, which remains misunderstood.
The present study reports two new records of the genus Pseudoboletia in the South and Southeastern Brazilian coast addressing morphological, molecular and biogeographic discussions.

\section{MATERIAL AND METHODS}

Collections: The sea urchins were collected using scuba diving in the Cabo Frio Island, Arraial do Cabo, Rio de Janeiro (22 $58^{\prime} 50^{\prime \prime} \mathrm{S}$; $\left.41^{\circ} 59^{\prime} 99^{\prime \prime} \mathrm{W}\right)$, in 2016 . The habitat consists of the interface of rocky boulders with sand flats at about 8-10 meters depth. Substratum coverage includes sparse turf algae and abundant crustose coralline algae (Fig. 1). At this specific site, a dozen of sea urchins could be found at the interface (rocky-sandy bottoms), however in this region the species is considered rare compared to other four mostly abundant species (Cordeiro et al., 2014). In the southeastern coast, one individual was photographed in Deserta Island, Florianópolis, Santa Catarina (2716'6.28's; 48 $\left.20^{\prime} 9.67^{\prime \prime} \mathrm{W}\right)$, in 2012 . The specimen was found at 8 meters depth over rocky boulders covered by thick turf algae and sharing space with Lytechinus variegatus. Therefore, the species is also considered rare at Deserta Island (Batista, pers. com.).

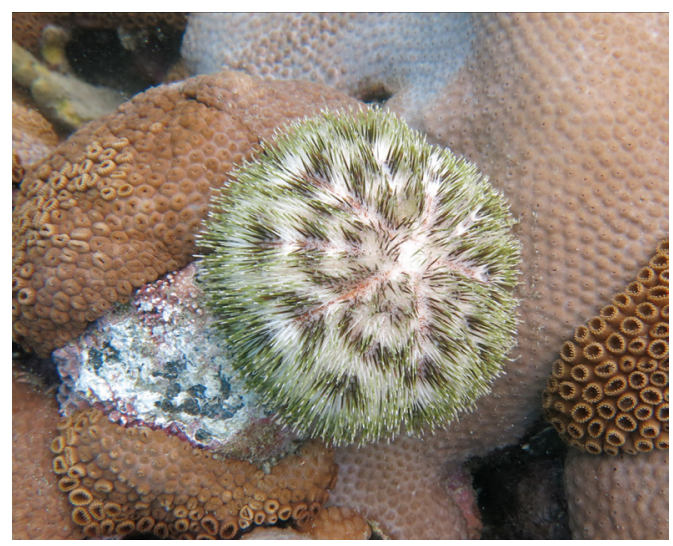

Fig. 1. Alive specimen in subtropical habitats of Arraial do Cabo, southeastern Brazilian coast.

Fig. 1. Espécimen vivo de Pseudoboletia en el hábitat subtropical de Arraial do Cabo, costa sureste de Brasil. 
Morphological analyses: The specimens were preserved in $95 \%$ ethanol, photographed, measured and deposited in the collection of the National Museum of the Rio de Janeiro (Universidade Federal do Rio de Janeiro, Brazil). Some individuals were treated with sodium hypochlorite solution $(\mathrm{NaClO})$ to remove all organic material, spines and pedicellariae in order to expose the morphological test characters. The valves of pedicellariae and spicules were also bleached, dehydrated (air-dried) and gold-coated in order to be photographed in a scanning electronic microscope (SEM) (JEOL JSM 6490LV). The morphological identification followed Mortensen (1943), Pawson (1978), and Turner and Graham (2003).

Molecular analyses: Molecular analyses were carried out in order to compare specimens from Brazil and specimens of the genus Pseudoboletia from other localities. The analyses included sequences obtained from the Genbank Database for Pseudoboletia maculata and Pseudoboletia indiana from Sydney (Australia), Pseudoboletia indiana from Easter Island (Chile) and Pseudoboletia sp. from São Tomé. All sequences were provided by Zigler et al. (2012). The species Lytechinus variegatus and Tripneustes ventricosus were used as outgroups.

Total DNA of the Brazilian specimens was extracted from preserved tube feet using a REDExtract-N-Amp Tissue PCR Kit (Sigma-Aldrich). MtDNA fragments of the Cytochrome $c$ Oxidase subunit I (COI) region were amplified using the forward primer $\mathrm{CO} 1 \mathrm{aPI}$ (5'-CGAGTACCGTCGAGGCATTCC-3') and the reverse primer COIf (5'-CCTGCAGGAGGAGGAGAYCC-3') as described by Zigler et al. (2012). Amplifications of DNA were performed using the REDExtract-N-Amp PCR Reaction Mix (Sigma-Aldrich). Cycling parameters consisted of an initial denaturation step of $94^{\circ} \mathrm{C} / 3 \mathrm{~min}$ followed by 35 cycles of $94^{\circ} \mathrm{C} / 30 \mathrm{sec}$, with an annealing temperature of $48-50^{\circ} \mathrm{C} / 1 \mathrm{~min}$ and $72^{\circ} \mathrm{C} / 1 \mathrm{~min}$ with a final extension step at $72^{\circ} \mathrm{C} / 10 \mathrm{~min}$. PCR products were visualized on $1.5 \%$ agarose gels stained with GelRed Nucleic Acid Gel Stain.
The PCR products were purified and sequenced at the Macrogen Inc. (South Korea). The sequences have been deposited in the Gen-Bank (accession numbers MG051273 MG051274). DNA sequences were aligned using the CLUSTALW algorithm with default parameters in software MEGA version 5.05 (Tamura et al., 2011) and were manually checked. Final aligned dataset included COI sequences of a total length of $561 \mathrm{bp}$. Maximum Likelihood (ML) tree were reconstructed in the software MEGA version 5.05 (Tamura et al., 2011) using HKY+ gamma model. The best-fit evolutionary model was calculated with jModelTest 0.1.1 (Posada, 2008) and selected by Akaike information criteria. Node support was evaluated using 1000 rapid bootstrap algorithms (Stamatakis, Hoover \& Rougemont, 2008). The genetic distances between the main clades were calculated under Kimura's twoparameter model (Kimura, 1980) in MEGA version 5.10 (Tamura et al., 2011).

Haplotype networks for COI sequences were estimated using the PEGAS package (Paradis, 2010) in the statistical program R (R Core Team, 2011) in order to provide an estimate of possible relationships among species and populations.

\section{RESULTS}

\section{Taxonomic account:}

Order Camarodonta Jackson, 1912

Infraorder Echinidae Kroh \& Smith, 2010

Family Toxopneustidae Troschel, 1872

Genus Pseudoboletia Troschel, 1869

Material examined: Five specimens collected in this work deposited in the Collection of the Echinodermata of National Museum/ Rio de Janeiro (collection numbers: EQMN 4396 (four wet specimens) and EQMN 4397 (one dry specimen). Rio de Janeiro/Brazil (22 $\left.2^{\circ} 58^{\prime} 50^{\prime} \mathrm{S} 41^{\circ} 59^{\prime} 99^{\prime \prime} \mathrm{W}\right)$, depth range 8-10 m, rocky substrate.

Description: The specimens show hemispheric test with about $75 \mathrm{~mm}$ and oral surface flat with deep and sharp buccal-notche. All 
specimens have maculae, pigmented spots of brown, randomly distributed through the white test. The spines on the aboral surface are about $10 \mathrm{~mm}$ long and those of the oral surface are about $15 \mathrm{~mm}$ long and slightly flattened distally. The spines of the macula are dark brown basally, faded green distally and white at the tip. The other spines are white basally with faded green and white bands in the middle to the tip. Brownish bands may be found in these spines (Fig. 2A-B).

Peristome is large with $25 \mathrm{~mm}$. The buccal plates are imbedded in the skin and carry a number of small spines, showing a bearded appearance around the mouth (Fig. 2A-B). There is one pair of buccal plates per ambulacral zone over peristomial membrane (Fig. 2C). The specimens show hemicyclic apical system with about $10 \mathrm{~mm}$ in diameter. Anal opening is subcentral (Fig. 2D).

There is one primary tubercle on each ambulacral plate. The secondary plates form a horizontal series in the ambital. The interambulacral region exhibits naked bands (Fig.2E). The ambulacral plates are polypored with four pore-pairs arranged in an arc in each plate (Fig. 2E). Four types of pedicellariae are found, globiferous, tridentate, ophicephalous
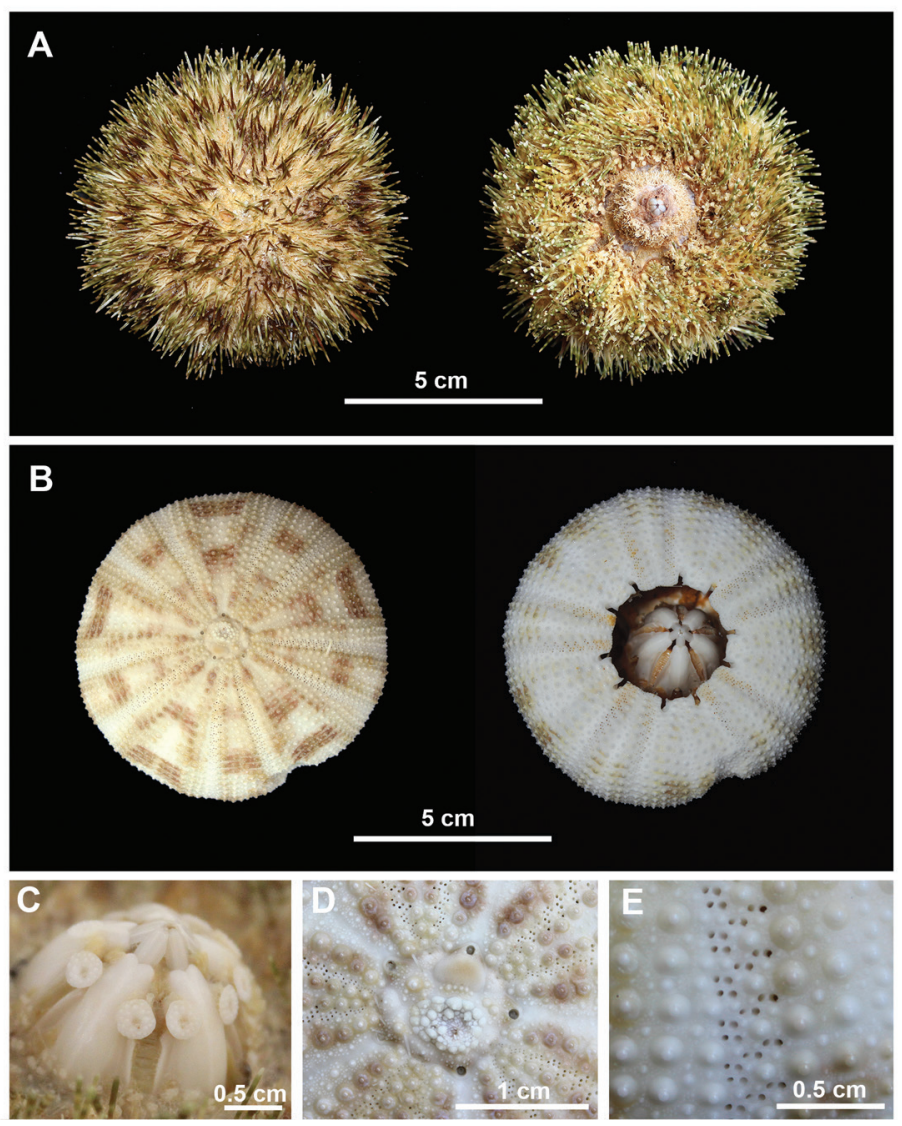

Fig. 2. Morphological details of the Brazilian specimen; A. Aboral and oral view; B. Aboral and oral view of the test; C. Aristotle's lantern in detail showing buccal plates; D. Apical system; and E. Ambulacral regions with four pore-pairs per plate.

Fig. 2. Detalle de la morfología de un specimen brasileño de Pseudoboletia; A. Vista oral y aboral, B. Vista oral y aboral de la testa; C. La linterna de Aristóteles que muestra en detalle las placas orales; D. Sistema apical; y E. Regiones ambulacrales con cuatro pares de poros por placa. 
and triphyllous (Fig. 3A-E). Small spicules (C-shaped type) are found in the skin of the pedicellaria (Fig. 3F).

Geographic range: The new records of the Pseudoboletia in the coasts of Rio de Janeiro and Santa Catarina (this study) together with the recent record to the Trindade Archipelago of the (Martins et al., 2016) expand the distribution range of this genus in the South-Western Atlantic region. The genus Pseudoboletia was previously recorded to: North-Western Atlantic (P. maculata and P. occidentalis), South-Eastern Atlantic Islands ( $P$. atlantica and Pseudoboletia sp.), Indian (P. maculata), Eastern
Pacific oceans ( $P$. indiana) and Indo-Pacific (P. indiana and P. maculata). The Indo-Pacific region exhibits sympatric areas between the two species. The distribution of the species of the Pseudoboletia and the new records in the Brazilian coast are showed in figure 4.

Molecular analyses: Phylogenetic trees reconstructed from the ML methods recovered three well-supported clades (Fig. 5A). The Pseudoboletia specimens from the Brazilian coast grouped together in the same clade with the specimens of the Pseudoboletia sp. from São Tomé. These Eastern Atlantic specimens differed from the Brazilian ones by a mean
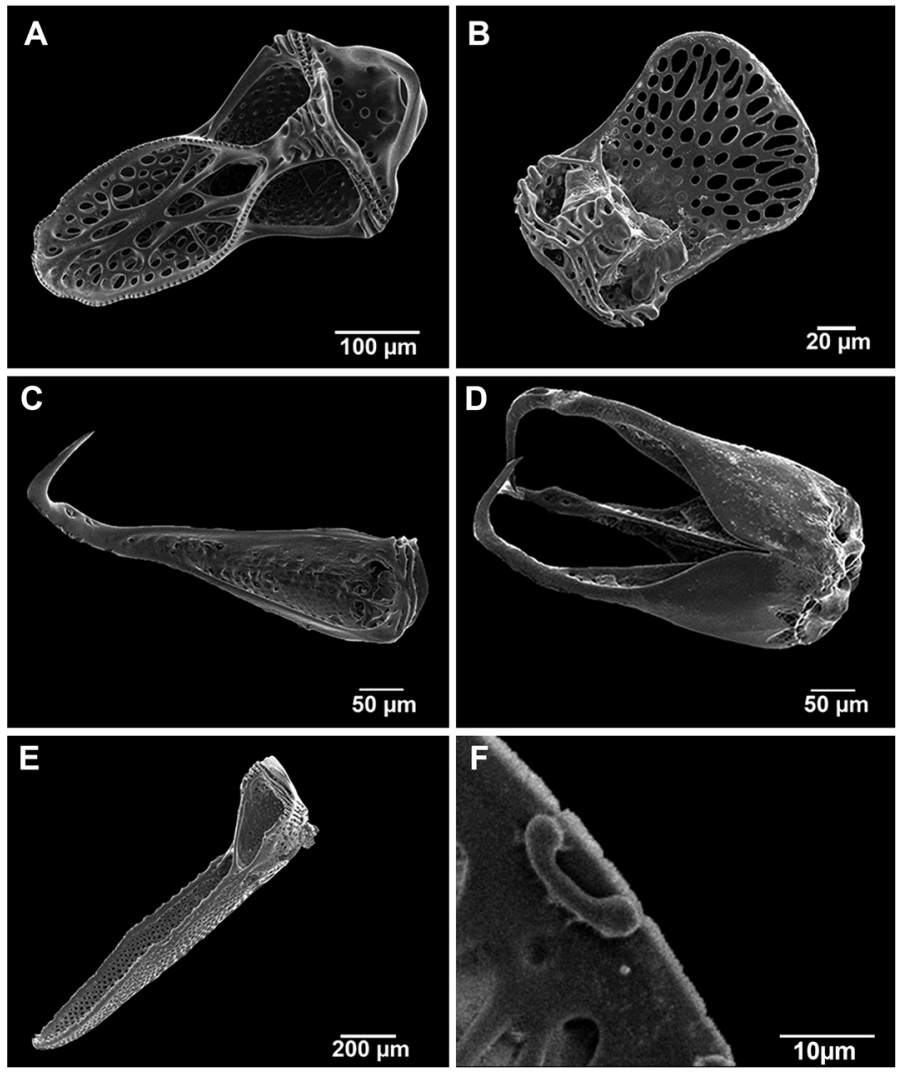

Fig. 3. Morphology of the pedicellariae of Pseudoboletia from Brazil; A. Valve of ophicephalous pedicellaria; B. Valves of triphyllous pedicellaria; C. Valve of globiferous pedicellaria; D. Globifera pedicellaria; E. Valve of tridentate pedicellaria; and F. C-shaped spicule over the skin of the pedicellaria.

Fig. 3. Morfología de los pedicelarios de Pseudoboletia de Brasil; A. Valva de los pedicelarios Oficéfalos; B. Valva de los pedicelarios Trifilos; C. Valva de los pedicelarios Globíferos; D. Pedicelario Globífero cerrado; E. Valva de los pedicelarios Tridentados; y F. Espículas en forma de C sobre el tejido de los pedicelarios. 


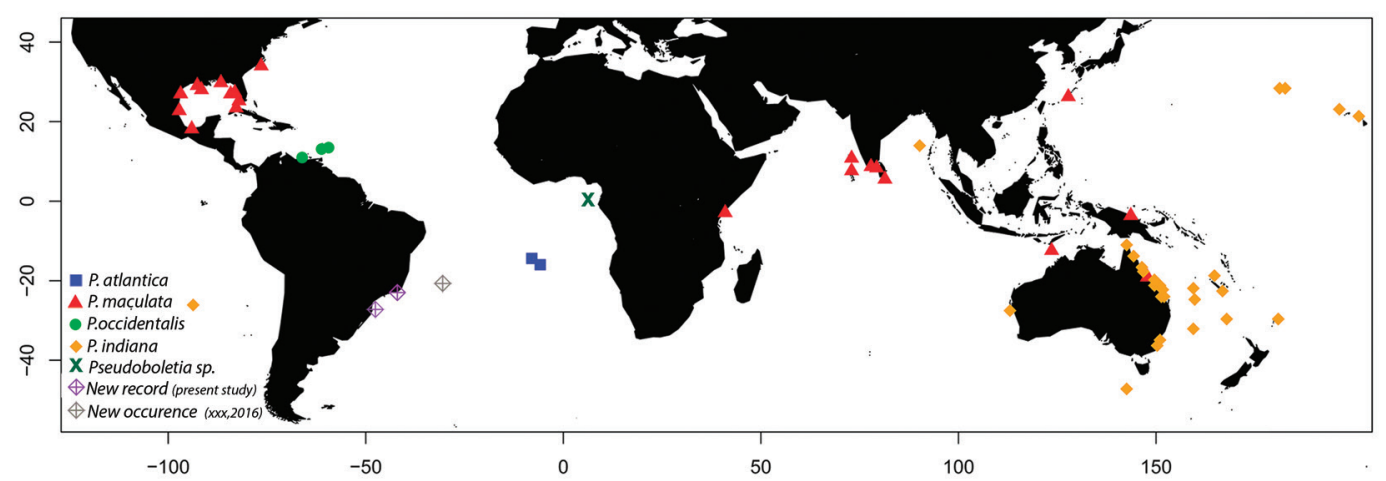

Fig. 4. Distribution of Pseudoboletia species based on the Ocean Biogeographic Information System (OBIS) database, Zigler et al. (2012), Mortensen (1943) and new registers (present study \& Martins et al., 2016).

Fig. 4. Distribución de las species de Pseudoboletia basada en las bases de datos del Sistema de Información Biogeográfica Oceánica (OBIS), Zigler et al. (2012), Mortensen (1943) y nuevos registros (present study \& Martins et al., 2016).

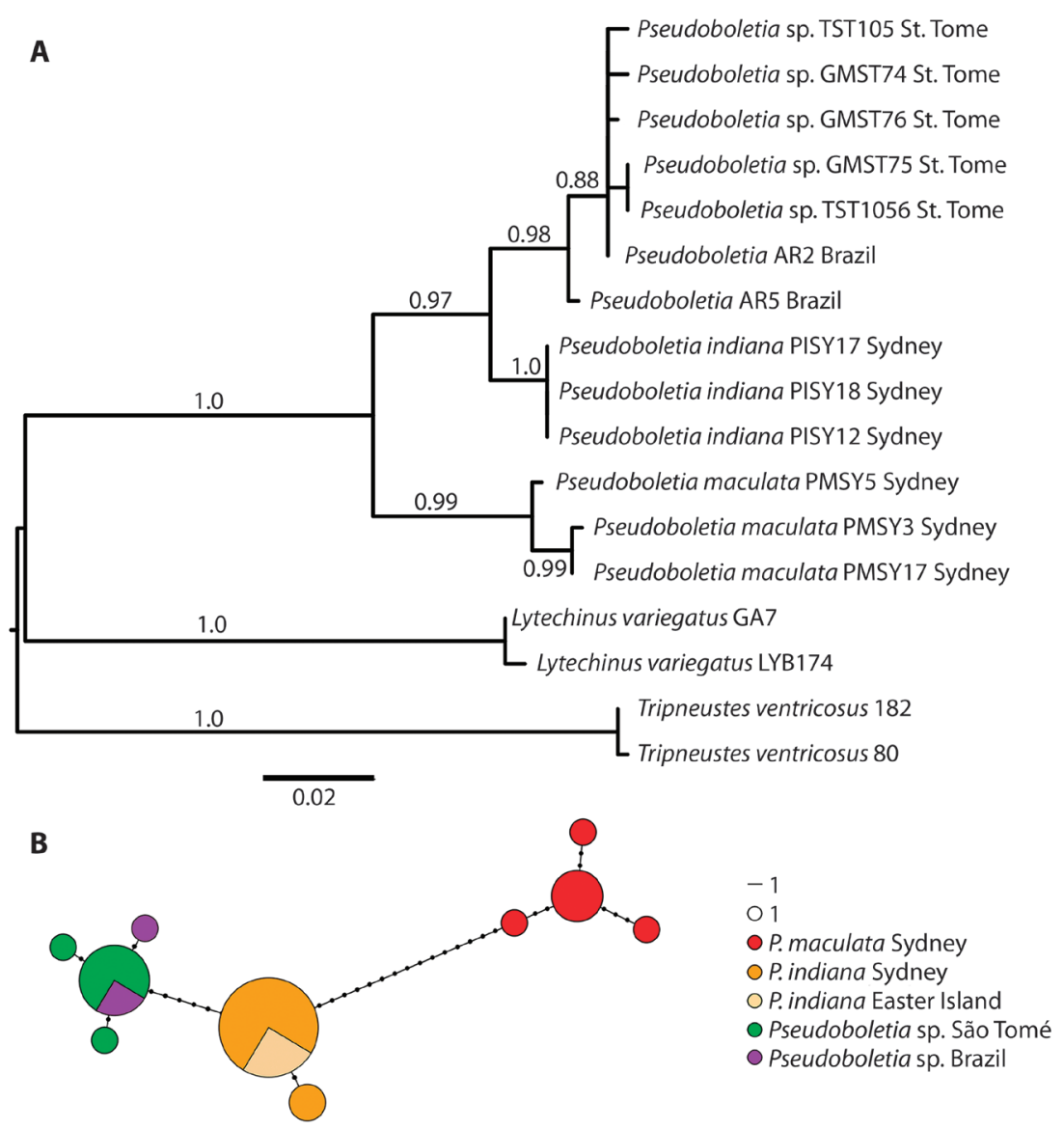

Fig. 5. A. Maximum likelihood tree based on COI sequences $(561 \mathrm{pb})$. Bootstrap score are shown on nodes; B. Haplotype Network.

Fig. 5. A. Árbol de maxima similitud basado en secuencias COI (561 pb). En los nodos se muestra la puntuación Bootstrap. B. Red de haplotipos. 
K2P genetic distance of $0.2 \%$. The Atlantic clade was recovered as a sister group of the clade that included specimens of Pseudoboletia indiana from Sydney (Australia) and Easter Island (Chile). The specimens of $P$. indiana from Pacific grouped in the same clade and differed by a mean K2P genetic distance of $0.3 \%$. The sister relationship between Pseudoboletia from Atlantic and Pseudoboletia from Pacific was well supported and differed by a mean K2P genetic distance of $2.3 \%$. Finally, the third clade included specimens of the Pseudoboletia maculata from Sydney. This clade was also well supported and differed from the other clades by a mean K2P genetic distance of 7.6\%. The statistical network analysis reconstructed three haplotype groups: one that included $P$. maculata from Sydney, another that included $P$. indiana with one haplotype shared between Eastern Island and Sydney, and the last one which included specimens from São Tomé and Brazil with one haplotype shared (Fig. 5B). The results suggested a connection between Brazil and São Tomé populations.

\section{DISCUSSION}

The recent records of the genus Pseudoboletia in Brazilian coast could be associated with two hypotheses: (1) a recent colonization of the Brazilian coast by a long-distance dispersal routes; or (2) a still and recent population expansion in the Brazilian coast after a period of low density.

The genetic analysis showed that Pseudoboletia from the Brazilian coast and São Tomé are genetically connected and are the same species. Genetic connectivity was also confirmed for populations of the sea urchins Eucidaris and Echinometra between Brazil and Africa (Lessios et al., 1999; McCartney, Keller, \& Lessios, 2000). However, the same pattern was not observed for the genera Diadema and Tripneustes (Lessios et al., 2001, 2003). According to Lessios et al. (2003), it is still unclear what are the attributes related to the different species for crossing the Mid Atlantic Barrier. For reef fishes, recent colonization in the Brazilian coast have been related to long distance dispersal across the Mid Atlantic Barrier following a East-to-West route (Luiz, Comin, \& Madin 2004; Floeter et al. 2008). Fish attributes are related to pelagic spawning, large size and maximum depth occurrence of species (Luiz et al., 2012). Some of these fishes have their origin in the Indo-Pacific Ocean. They were able to overcome the Benguela barrier, and colonize habitats in the African coast before dispersing to Brazilian coast (Rocha et al., 2005; Bowen et al., 2006).The dispersal route extending from African coast directly to the Brazilian coast has been pointed as a common one (Luiz, Floeter, Gasparini, Ferreira, \& Wirtz, 2004; Rocha et al., 2005; Bowen et al., 2006; Luiz et al., 2014; Lastrucci, 2016). The Mid-Atlantic islands of Ascension and St. Helena are important stepping-stones for colonization from Western Atlantic to Eastern Atlantic (Rocha et al., 2005; Bowen et al., 2006). According to Scheltema (1971), this current transport from Africa to Brazil takes about 70 days. Pseudoboletia, as well as the other toxopneustids, has a planctotrophic larva with longlife pelagic period (echinopluteus) (Byrne \& Voltzow, 2004). Therefore, the hypothesis that sea urchin larvae arrived in Brazilian coast by recent long-distance dispersal following a route East-to-West into the Atlantic via Mid-Atlantic Island should be considered. This dispersal route is compatible with the records of these genus along the Atlantic Ocean: São Tomé Island (East Atlantic coast); St. Helena and Ascension Island (Mid-Atlantic ocean); Trindade Archipelago, off the Southeastern Brazilian coast (West Atlantic coast); and shoreline regions of the South and Southeastern of the Brazil (West Atlantic coast). However, the relationship among North-Western Atlantic (Caribbean-Gulf of Mexico) and South Atlantic populations (Africa-Brazil) should be analyzed in order to clarify the biogeographic scenario of this genus along the Atlantic Provinces.

Echinoderms are known as a boom-buRst phylum because they suffer from large population fluctuations (Uthicke, Schaffelke, \& Byrne, 2009; Lessios, 2013). Population booms 
and mass mortality events are widely reported for toxopneustid genera like Lytechinus and Tripneustes (Scheibling \& Mladenov, 1987; Williams et al., 1996; Beddingfield \& McClintock, 2000; Haley \& Solandt, 2001; Moses \& Bonem, 2001; Lessios, 2013). Changes in population density in echinoids can be related to broadcast spawning and planktotrophic larval life-history traits, which can be accentuated by disproportional recruitment events and juvenile survivorship (Uthicke et al., 2009; Lessios, 2013). Anthropogenic disturbance including climate changes and disease outbreaks can also have influence on boom-buRst cycles (Lessios, 2013). Therefore, the recent records of the Pseudoboletia in Brazilian coast could be related to a population expansion event.

The taxonomy of the genus Pseudoboletia is not clear. Basically, two morphological characters discriminate the species: (1) number of pore-pairs per plate and (2) presence of macula in spines and the test. The molecular results differentiated three species, two species from the Indo-Pacific ( $P$. indiana and $P$. maculata) and one species from the Atlantic (Pseudoboletia sp. from São Tome and Brazil) (Fig. 5). Clearly, individuals named as $P$. maculata from the Atlantic and those from the Indo-Pacific are not the same species and should be reclassified. The morphology of the individuals of the Pseudoboletia from Brazil is compatible with $P$. maculata maculata, due to color pattern of the spines and spots (macula) on test and also due to the presence of four pore-pair of podia. Martins et al. (2016) referred the individuals from Archipelago of Trindade as $P$. maculata. Different from here, the description of the Pseudoboletia from Trindade-Martin Vaz insular complex did not reported tridentate pedicellariae (Martins et al., 2016). However, following Zigler et al. (2012) suggestion, careful analysis is needed before referring these individuals as $P$. maculata. The species $P$. atlantica, characterized by having four pore-pair plates, was described as endemic of St. Helena and Ascension islands (Mortensen, 1943). The presence of the five pore-pair plates is the only difference that distinguishes $P$. maculata from
P. atlantica. St. Helena-Ascension Province (Mid-Atlantic Ridge Province-MAR) has high connectivity with the Brazilian Province and the Tropical Eastern Atlantic Province (TEA), which includes São Tomé and Principe Island, mainly due to the prevailing current patterns (Floeter et al., 2008; Briggs and Bowen 2012; Luiz et al., 2012). Therefore, morphology of the specimens from St. Helena and Ascension islands should be reassessed, as well as new molecular analysis.

Due to taxonomic uncertainness, a systematic review of this genus is very necessary. Additionally, it is strongly recommended that representative samples from different biogeographical provinces be analyzed under both morphological and molecular approaches to understand the evolutionary history of the genus.

\section{RESUMEN}

Ocurrencia del género Pseudoboletia (Echinoidea: Toxopneustidae) en el Atlántico suroeste: acercamientos morfológicos y moleculares. El género Pseudoboletia fue recientemente reportado para la costa de Brasil (complejo insular Trinidade-Martin Vaz). Este estudio reporta por primera vez a este género en el sur de Brasil en las costas de Río de Janeiro y Santa Catarina. Los datos morfológicos y moleculares muestran que los erizos de mar de Brasil y São Tomé son la misma especie, genéticamente diferente de individuos del Indo-Pacífico. Sin embargo, la identidad taxonómica de las especies de Brasil se mantiene como un reto. Se discuten dos hipótesis para explicar los recientes récords de esta especie en la costa brasileña: una invasión natural reciente por dispersión a larga distancia y una reciente expansión de la población en la costa brasileña luego de una ausencia de un periodo de baja densidad.

Palabras claves: erizo de mar; costa brasileña; nuevo récord; expansión de la población; dispersión a larga distancia.

\section{REFERENCES}

Beddingfield, S. D., \& McClintock, J. B. (2000). Demographic characteristics of Lytechinus variegatus (Echinoidea: Echinodermata) from three habitats in a North Florida Bay, Gulf of Mexico. Marine Ecology, 21(1), 17-40.

Bowen, B. W., Muss, A., Rocha, L. A., \& Grant, W. S. (2006). Shallow mtDNA coalescence in Atlantic pygmy angelfishes (genus Centropyge) indicates a 
recent invasion from the Indian Ocean. Journal of Heredity, 97(1), 1-12.

Briggs, J. C., \& Bowen, B. W. (2012). A realignment of marine biogeographic provinces with particular reference to fish distributions, 12-30.

Byrne, M., \& Voltzow, J. (2004). Morphological evolution in sea urchin development: Hybrids provide insights into the pace of evolution. BioEssays, 26(4), 343-347.

Cordeiro, C. A. M. M., Harborne, A. R., \& Ferreira, C. E. L. (2014). Patterns of distribution and composition of sea urchin assemblages on Brazilian subtropical rocky reefs. Marine Biology, 161(10), 2221-2232.

Floeter, S. R., Rocha, L. A., Robertson, D. R., Joyeux, J. C., Smith-Vaniz, W. F., Wirtz, P., ... Bernardi, G. (2008). Atlantic reef fish biogeography and evolution. Journal of Biogeography, 35, 22-47.

Haley, M. P., \& Solandt, J. L. (2001). Population fluctuations of the sea urchins Diadema antillarum and Tripneustes ventricosus at Discovery Bay, Jamaica: A case of biological succession? Caribbean Journal of Science, 37(3-4), 239-245.

Kimura, M. (1980). A simple method for estimating evolutionary rate of base substitutions through comparative studies of nucleotide sequences. Journal of Molecular Evolution, 16, 111-120.

Lastrucci, N. S. (2016). Filogeografia e atividade alimentar do gênero Ophioblennius no oceano Atlântico. Universidade Federal de Santa Catarina, Florianópolis. $59 \mathrm{pp}$.

Lessios, H. A., Kessing, B. D., \& Pearse, J. S. (2001). Population Structure and Speciation in Tropical Seas: Global Phylogeography of the Sea Urchin Diadema. Evolution, 55(5), 955.

Lessios, H. A., Kane, J., \& Robertson, D. R. (2003). Phylogeography of the pantropical sea urchin Tripneustes: contrasting patterns of population structure between oceans. Evolution, 57(9), 2026.

Lessios, H. A. (2013). Natural population density fluctuations of echinoids do they help predict the future? In: J. M. Fernandez-Palacios, L. de Nascimento, J. C. Hernandez, S. Clemente, A. Gonzalez, \& J. P. DiazGonzalez (Eds.), Climate change perspectives from the Atlantic: past, present and future (pp. 341-359). La Laguna, España: Servicio de Publicaciones, Universidad de La Laguna.

Liao, Y., \& Clark, A. M. (1995). The Echinoderms of Southern China. Beijing: Science Press.
Luiz, O. J., Floeter, S. R., Gasparini, J. L., Ferreira, C. E. L., \& Wirtz, P. (2004). The occurrence of Acanthurus monroviae (Perciformes: Acanthuridae) in the southwestern Atlantic, with comments on other eastern Atlantic reef fishes occurring in Brazil. Journal of Fish Biology, 65(4), 1173-1179.

Luiz, O. J., Madin, J. S., Robertson, D. R., Rocha, L. A., Wirtz, P., \& Floeter, S. R. (2012). Ecological traits influencing range expansion across large oceanic dispersal barriers: insights from tropical Atlantic reef fishes. Proceedings of the Royal Society B: Biological Sciences, 279(1730), 1033-1040.

Luiz, O. J., Comin, E. J., \& Madin, J. S. (2014). Far away from home: the occurrence of the Indo-Pacific bannerfish Heniochus acuminatus (Pisces: Chaetodontidae) in the Atlantic. Bulletin of Marine Science, 90(2), 741-744.

Martins, L., Souto, C., Braga, J., \& Tavares, M. (2016). Echinoidea and Holothuroidea (Echinodermata) of the Trindade and Martin Vaz Archipelago, off Brazil, with new records and remarks on taxonomy and species composition. Journal of the Marine Biological Association of the United Kingdom, 1-35.

McCartney, M. A., Keller, G., \& Lessios, H. A. (2000). Dispersal barriers in tropical oceans and speciation in Atlantic and eastern Pacific sea urchins of the genus Echinometra. Molecular Ecology, 9(9), 1391-1400.

Mortensen, T. (1943). A monograph of the Echinoidea. III. 2, 3. Camarodonta. 553 pp. (C. A. Rietzel, Ed.). Copenhagen.

Moses, C. S., \& Bonem, R. M. (2001). Recent population dynamics of Diadema antillarum and Tripneustes ventricosus along tha north coast of Jamaica, W.I. Bulletin of Marine Science, 68(2), 327-336.

Paradis, E. (2010). pegas: an R package for population genetics with an integrated-modular approach. Bioinformatics, 26(3), 419-420.

Pawson, D. L. (1978). The echinoderm fauna of Ascension island, South Atlantic ocean. Smithsonian Contributions to the Marine Sciences, 2(2), 1-31.

Posada, D. (2008). jModelTest: Phylogenetic model averaging. Molecular Biology and Evolution, 25, 1253-1256.

R Core Team. (2011). R: A Language and environment for statistical computing. $R$ Foundation for Statistical Computing, 409. 
Rocha, L. A., Robertson, D. R., Rocha, C. R., Van Tassell, J. L., Craig, M. T., \& Bowen, B. W. (2005). Recent invasion of the tropical Atlantic by an IndoPacific coral reef fish. Molecular Ecology, 14(13), 3921-3928.

Scheibling, R. E., \& Mladenov, P. V. (1987). The decline of the sea urchin, Tripneustes ventricosus, fishery of barbados: a survey of fishermen and consumers. Marine Fisheries Review, 49, 62-69.

Scheltema, R. S. (1971). The dispersal of the larvae of shoal-water benthic invertebrate species over long distances by ocean currents. In: Fourth European Marine Biology Symposium (pp. 7-28).

Stamatakis, A., Hoover, P., \& Rougemont, J. (2008). A rapid bootstrap algorithm for the RAxML Web servers. Systematic Biology, 57, 758-771.

Tamura, K., Peterson, D., Peterson, N., Stecher, G., Nei, M., \& Kumar, S. (2011). MEGA5: Molecular evolutionary genetics analysis using maximum likelihood, evolutionary distance, and maximum parsimony method. Molecular Biology and Evolution, 28, 2731-2739.
Turner, R. L., \& Graham, B. D. (2003). Calocidaris micans (Cidaridae) and Pseudoboletia maculata (Toxopneustidae): additions to the sea urchin fauna (Echinodermata: Echinoidea) of the Gulf of Mexico. Proceedings of The Biological Society of Washington, $116,61-81$.

Uthicke, S., Schaffelke, B., \& Byrne, M. (2009). A boom-bust phylum? Ecological and evolutionary consequences of density variations in echinoderms. Ecological Monographs, 79(1), 3-24.

Williams, J. E. H., Bunkley-Williams, L., Bruckner, R. J., Bruckner, A. W., Ortiz-Corps, E. A. R., Bowden-Kerby, W. A., \& Colon-Jones, D. E. (1996). Recurring mass mortalities of the white-spined sea urchin, Tripneustes ventricosus, (Echinodermata: Echinoidea) in Puerto Rico. Caribbean Journal of Science, 32(1), 111-112.

Zigler, K. S., Byrne, M., Raff, E. C., Lessios, H. A., \& Raff, R. A. (2012). Natural hybridization in the sea urchin genus Pseudoboletia between species without apparent barriers to gamete recognition. Evolution, 66(6), 1695-1708. 